\title{
HOMENAGEM À RUI MAURO MARINI
}

HOMAGE TO RUI MAURO MARINI

HOMENAJE A RUI MAURO MARINI

\section{Simone Rodrigues Pinto}

Doutora em Ciência Política

Universidade de Brasília

Brasil

smartinsrodrigues@hotmail.com

\section{Resumo:}

Texto elaborado por Simone Rodrigues Pinto em homenagem ao intelectual de esquerda Rui Mauro Marini.

Palabras clave: Rui Mauro Marini, teoria da dependência, América Latina, Brasil.

\section{Resumen:}

Texto elaborado por Simone Rodrigues Pinto en homenaje al intelectual de izquierda Rui Mauro Marini.

Palabras clave: Rui Mauro Marini, teoría de la dependencia, América Latina, Brasil. 


\section{Abstract:}

Text prepared by Simone Rodrigues Pinto in honor of the intellectual left Rui Mauro Marini.

Keywords: Rui Mauro Marini, dependency theory, Latin America, Brazil.

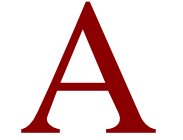

o ministrar minhas classes de pensamento social e político latino-americano não posso deixar de me deter no legado de Rui Mauro Marini. Apesar da surpresa (já nem tanto presente) de constatar que meus estudantes da Universidade de Brasília pouco ou nada conhecem sobre este grande intelectual marxista brasileiro, não deixo de me deleitar em apresentar seu maior legado, a dialética da dependência.

Muito mais conhecido (e reconhecido) na América Latina que no Brasil, Rui Mauro Marini foi um intelectual engajado e compromissado com o conhecimento para entender a realidade para transformá-la. Segundo Jaime Osório, homem que apresentava qualidades humanas, acompanhadas de grandes capacidades teóricas e políticas em uma fusão pouco frequente no gênero humano. Sua militância pelo fim das desigualdades sociais e seu pensamento sofisticado merecem assim registro no cânon das ciências sociais. Por isso essa homenagem em um volume focado no papel das esquerdas no mundo.

Sua vida foi marcada por uma militância "com rigor científico" a favor do fim das desigualdades. Muito jovem teve contato com o marxismo na França, onde foi bolsista, e trouxe para o Brasil o compromisso de criar um partido

\footnotetext{
${ }^{1}$ A possibilidade de Habeas Corpus foi encerrada em 1968, acirrando as condições da ditadura.
}

revolucionário. Ainda como estudante de Administração Pública e de Empresas na UFRJ ajudou a criar a organização revolucionária marxista Política Operária.

Convidado por Darcy Ribeiro, passou a ser professor da Universidade de Brasília em 1963, onde organizou junto com Theotonio dos Santos e Vania Bambirra, o círculo de estudos de O Capital que pretendia analisar as sociedades latino-americanas à luz da teoria marxista. Era um momento político conturbado no Brasil, onde o debate político girava em torno de uma polarização perigosa entre Capitalismo e Socialismo como soluções para os problemas de desenvolvimento da época. A balança foi definida por meio de um golpe militar seguido de ditadura civil-militar que passou a perseguir violentamente qualquer indício de ideias marxistas. Rui Mauro foi demitido da UnB, junto com outros professores, como parte do expurgo da academia em todo o Brasil.

A partir do golpe e da ditadura implantada em 1964, passou a sofrer forte vigilância por parte dos militares. Seu filho conta que todas as noites um suboficial da aeronáutica batia à sua porta, sentava em sua sala na presença da família, ainda sem nada fazer, até que sua prisão foi efetivada em julho do mesmo ano. Preso e torturado no CENIMAR por seis meses, conseguiu um Habeas Corpus ${ }^{1}$ que facilitou seu exílio no México. Lá foi professor e pesquisador 
no Colégio do México entre 1965 e 1969, escrevendo para periódicos no México, no Chile e em Cuba. Quando se acirrou o confronto no México com o movimento estudantil, iniciado em 1968, Rui Mauro foi identificado como um dos intelectuais incitadores do movimento e foi "convidado" pela polícia mexicana a sair imediatamente do país.

Do México foi para o Chile, onde as lutas populares estavam muito ativas. Chegou como professor da Universidade do Chile e vinculado ao Movimiento de Izquierda Revolucionário (MIR) até a queda de Salvador Allende em 1973. É neste período de pujança da esquerda no Chile que Rui Mauro escreve sua principal obra, a Dialética da Dependência. Durante a ditadura de Pinochet no Chile não teve outra opção senão retornar ao México para continuar seu exílio. Somente em 1986 retornou ao Brasil e à UnB, no departamento de Ciência Política. Seu retorno foi doloroso já que encontra um Brasil cujas desigualdades sociais haviam sido acirradas pelas políticas econômicas da ditadura, que aumentaram drasticamente o abismo entre ricos e pobres, e com uma população cuja capacidade de reflexão crítica estava reduzida após anos de censura e perseguição política.

No campo do pensamento, Rui Mauro está identificado como um dos criadores da Teoria da Dependência nos anos sessenta e setenta do século XX. O avanço do capital estrangeiro e a frustração com a perspectiva de desenvolvimento de um capitalismo autônomo por parte de uma burguesia industrial gerou descrença em relação ao sucesso do modelo desenvolvimentista que, associada ao debate sobre o processo cubano, abriram espaço para o surgimento das teorias da dependência. O tema das particularidades do capitalismo periférico ou dependente torna-se central na CEPAL e no Instituto Latino-americano de Planificação Econômica e Social (ILPES), organismo ligado à CEPAL, neste período.

O novo modelo de interpretação durante esta nova conjuntura se inaugura com a publicação dos textos de Andre Gunder Frank, Rodolfo Stavenhagen, Fernando Henrique Cardoso e Enzo Faletto e Ruy Mauro Marini e passa a ser denominado de dependentismo. Os adeptos das teorias dependentistas formularam seu diagnóstico a partir da crítica à teoria da modernização e do desenvolvimentismo que prevaleciam na vida intelectual latinoamericana nas décadas de cinquienta e sessenta.

Em comum, os dependentistas têm a crítica aos enfoques centrados na sociedade nacional, como contexto analítico prioritário. Para eles, deve-se compreender o desenvolvimento econômico latino-americano dentro da dinâmica geral de inserção histórica do continente no processo global de expansão capitalista. $\mathrm{O}$ centro e a periferia estão ligados a um sistema global cujas características originais foram descritas por Lênin, quando aponta o imperialismo como uma fase superior do capitalismo. Neste mundo, em que o sistema econômico é único, as economias subdesenvolvidas se articulam com o sistema econômico mundial mediante a transferência de recursos da periferia para o centro. Este intercâmbio desigual gera impedimentos ao desenvolvimento dos países latinoamericanos.

Rui Mauro Marini é responsável por um enfoque mais marxista da dependência, ressaltando novos fenômenos ligados à 
superexploração do trabalho e ao subimperialismo. Apesar de sua base de reflexão ser eminentemente o contexto brasileiro, sua proposição central transcende este limite geográfico para afirmar que a história do subdesenvolvimento latino-americano está estreitamente ligada ao desenvolvimento do capitalismo mundial. Só através da compreensão dos mecanismos que caracterizam a economia capitalista mundial pode-se elaborar um marco adequado para situar a problemática da América Latina.

Marini distingue três grandes períodos para a interpretação do processo de desenvolvimento: a) período de economia exportadora de 1870 a 1929, em que a periferia sustenta a expansão capitalista; b) período da economia industrial de 1929 a 1964, onde a indústria tem um papel complementar ao setor exportador, refletido na relação entre a burguesia e os latifundiários e c) de 1964 em diante, quando inicia a crise do modelo anterior e a intervenção do capital estrangeiro no setor industrial. A partir dessa periodização, Marini identifica a dependência como uma relação de subordinação entre nações formalmente independentes, mas que mantêm uma relação de subordinação e dependência de umas sobre as outras. Para ele, subdesenvolvimento e dependência estão estreitamente ligados porque o desenvolvimento dos países centrais só é possível em função de sua possibilidade de explorar a periferia. E, a pobreza da periferia é derivada da espoliação de seus excedentes feita pelos países centrais. Assim, a formação do capitalismo dependente só pode ser entendida em

\footnotetext{
${ }^{2}$ Fernando Henrique Cardoso e José Serra publicam em um artigo em que atacam
}

função da acumulação de capital em escala mundial e da superexploração do trabalho. Superexploração por ele é entendida como precarização exacerbada da mão de obra e o esvaziamento dos espaços de luta no mundo do trabalho, que, juntamente com o subimperialismo representado pela expropriação de nosso território e de nossa economia por empresas transnacionais para expansão e controle de outros mercados, capitaneada pela privatização de setores estratégicos das economias latinoamericanas... esses são os principais elos da opressão e da desigualdade social. Dessa forma, não posso deixar de ver a continuidade e atualidade dos conceitos de superexploração do trabalho e de subimperialismo.

No estudo da Teoria da Dependencia nas academias brasileiras, diferentemente de outros centros importantes na América Latina, tem prevalecido a versão construída por Fernando Henrique Cardoso ${ }^{2}$ e permanecem invizibilizados outros intelectuais com interpretações diferenciadas a respeito da dependência latino-americana. Portanto, revisitar autores como Rui Mauro Marini é uma necessidade e um impulso para o cientista social brasileiro e latino-americano.

fortemente as ideias de Rui Mauro Marini. A resposta de Marini não foi publicada no Brasil. 